\title{
Ansvar for skade voldt av romgjenstand
}

\author{
Professor Trine-Lise Wilhelmsen \\ Universitet i Oslo, Nordisk institutt for sjørett, Det juridiske fakultet
}

\section{Sammendrag}

Artikkelen analyserer utkast til regler om ansvar, regress og forsikring i forslag til ny lov om aktivitet i verdensrommet med utgangspunkt i mandatet fra departementet og setter reglene $\mathrm{i}$ et noe bredere perspektiv enn utvalget gjorde. Problemstillingen er viktig fordi Norge planlegger kommersiell oppskytning fra Andøya som også inkluderer utenlandske deltagere. Artikkelen gjennomgår reglene om statens internasjonale ansvar for skade voldt av romgjenstand som bakgrunn for utkastet, spørsmål knyttet til jurisdiksjon og lovvalg i internasjonale erstatningssaker og utvalgets forslag til regler i lys av bl.a. alminnelig norsk erstatningsrett og hensynet til verdiskaping.

\section{Innledning}

Temaet for denne artikkelen er ansvar for skade voldt av romgjenstand. Med romgjenstand menes her enhver gjenstand eller del av gjenstand som brukes i aktivitet i verdensrommet, typisk raketter og satellitter eller annen nyttelast om bord i raketter. Med aktivitet $\mathrm{i}$ verdensrommet eller romaktivitet menes skyting av romgjenstander ut i verdensrommet, drift av slike gjenstander, og retur til bakken. I Norge er utskytning av romgjenstander i dag regulert av Lov om oppskyting av gjenstander fra norsk territorium m.m. ut i verdensrommet. ${ }^{1}$ Loven ble vedtatt for å overholde Norges forpliktelser etter Romtraktaten som ble vedtatt i 1967, ${ }^{2}$ og sier i tråd med denne at det kreves tillatelse for å skyte noen gjenstand ut i verdensrommet fra områder underlagt norsk jurisdiksjon eller av norsk statsborger. ${ }^{3}$ Loven har ingen regler om ansvar for skade voldt av romgjenstand.

\footnotetext{
LOV-1969-06-13-38 (1969-loven).

Treaty on Treaty on Principles Governing the Activities of States in the Exploration and Use of Outer Space, including the Moon and Other Celestial Bodies, (Romtraktaten) http://www.unoosa.org/oosa/en/ourwork/spacelaw/treaties/outerspacetreaty.html Romtraktaten art. VI, 1969-loven $\S 1$.
} 
Etter vedtagelsen av loven har Norge ratifisert 3 konvensjoner om romfart, ${ }^{4}$ herunder Ansvarskonvensjonen av 29 mars 1972 som bl.a. pålegger oppskytende stat et objektivt ansvar for skader voldt av romgjenstand på jordoverflaten og fly under flygning. I de senere år har det også skjedd en omfattende utvikling i den norske og internasjonale romfartsindustrien. Den nye romalderen er karakterisert av at romaktivitet ikke lenger er forbeholdt stormaktene eller statlige aktører. Billigere, enklere, og bedre teknologi har gitt tilgang til verdensrommet for flere typer aktører og åpnet for flere nye aktiviteter. Dette har ført til et stadig økende aktivitetsnivå i rommet. ${ }^{5}$ Likevel er det fremdeles få utskytningsanlegg for romgjenstander i verden. Norge har imidlertid et slikt anlegg på Andøya, og det planlegges nå kommersiell utskytning fra dette anlegget med deltagelse både av norske og internasjonale aktører. ${ }^{6}$

Denne utviklingen har ført til et generelt behov for å modernisere 1969-loven. Nærings- og fiskeridepartementet nedsatte derfor 15 . januar 2019 et ekspertutvalg for å utarbeide forslag til ny lovtekst med forarbeider. Utvalgets utredning Rett i bane ble overlevert departementet 4 . februar 2020. Departementet begrunner i mandatet behovet for ny lov med at eksisterende lovgivning anses foreldet og ikke håndterer Norges internasjonale forpliktelser på en tilfredsstillende måte, og at det er behov for en fremtidsrettet regulering som bidrar til norsk verdiskaping og næringsutvikling. ${ }^{7}$

Artikkelforfatteren var formann i utvalget og utviklet reglene i utkastet om ansvar og forsikring for skade voldt av romgjenstand. Forslaget har 4 hovedkomponenter:

Regressansvar for operatøren hvis staten må betale erstatning i henhold til sine internasjonale forpliktelser, objektivt ansvar for operatøren etter mønster av statens internasjonale ansvar, begrensning av både erstatningsansvaret og regress ansvaret og obligatorisk forsikring eller annen sikkerhet. ${ }^{8}$ Denne artikkelen ble i utgangspunktet skrevet som et grunnlag for utvalgets vurderinger av disse spørsmålene. En del av forfatterens synspunkter er derfor allerede publisert i Rett i bane kap. 13, jf. også kap. 5.3. Hensikten her er å videreutvikle noen av perspektivene i utredningen for å sette vurderingene inn i en bredere ramme både i forhold til mandatet og til alminnelig norsk erstatningsrett. Dette gjelder for det første spørsmål knyttet

4 Agreement on the Rescue of Astronauts, the Return of Astronauts and the Return of Objects Launched into Outer Space http://www.unoosa.org/oosa/en/ourwork/spacelaw/treaties/rescueagreement.html Convention on International Liability for Damage Caused by Space Objects (Ansvarskonvensjonen) http://www.unoosa.org/oosa/en/ourwork/spacelaw/treaties/liability-convention.html Convention on Registration of Objects Launched into Outer Space (Registreringskonvensjonen) http://www.unoosa.org/oosa/en/ourwork/spacelaw/treaties/registration-convention.html

$5 \quad$ NRS-Rapport (2017)1 s. 5. Se også Rett i bane, Utredning fra utvalg oppnevnt av Nærings- og fiskeridepartementet til å foreslå ny lov om aktivitet i verdensrommet, Rapport fra Nærings- og fiskeridepartementet (Rett i bane) kap. 4.

6 Rett i bane, s. 19. Rett i bane, s. 15 .

Se utkastet $\S \S 21-25$, Rett i bane s. 10. 
til jurisdiksjon og lovvalg. Romindustrien er internasjonal og en romgjenstand kan volde skade hvor som helst. Spørsmål om jurisdiksjon og lovvalg er berørt i utredningen, men drøftes grundigere i kap. 4 nedenfor. For det andre har det interesse å sette utkastets forslag til objektivt ansvar inn i en bredere norsk erstatningsrettslig ramme, særlig i lys av HR-2019-52 A «Spinning», jf. kap. 5.3.2. For det tredje kan departementets målsetning om verdiskaping og næringsutvikling videreutvikles i to retninger. Den første gjelder det komparative aspektet av reglene for å sikre like rettslige konkurransevilkår for en internasjonal romindustri. Internasjonal harmonisering er for $\varnothing$ vrig også vesentlig for å sikre at skadelidtes posisjon i tråd med Ansvarskonvensjonen blir den samme uansett hvor skaden rammer. Den andre gjelder spørsmålet om forslaget bidrar til samfunnsmessige effektive regler for å sikre målet om verdiskaping. Her utvides perspektivet med et innslag av rettsøkonomi som ikke er tatt med i Rett i bane. Disse perspektivene gjelder hele fremstillingen av utkastet til ansvarsregler i kap. 5 nedenfor.

Innledningsvis er det nødvendig til å gi en oversikt over rettskildebildet og det komparative aspektet i kapittel 2 og over Norges internasjonale forpliktelser etter konvensjonene i kapittel 3. Norges internasjonale forpliktelser gir en ramme for utkastet og er nødvendig for å forstå forholdet mellom ansvar og regress i utvalgets forslag og også forslaget om objektivt ansvar.

\section{Rettskildegrunnlaget - det komparative aspektet}

De internasjonale Rom-konvensjonene gjelder forholdet mellom de stater som er part i traktatene. I tillegg er det utviklet en internasjonal modell-lov for nasjonal regulering av romfart (Sofia-modellen). ${ }^{9}$ I departementets mandat peker man særlig på utviklingen av internasjonale regler som grunnlag for behov for ny lov, og utvalget så derfor gjennomgående på løsningene i denne modellen, også for reguleringen av ansvar og forsikring. I tillegg hadde utvalget generelt en komparativ innretning. Her fokuserte man i første rekke på nordisk rett og særlig på finsk og dansk rett hvor det foreligger ny lovgivning. ${ }^{10}$ Dette ble ansett som hensiktsmessig pga. nordisk rettsenhet og felles rettskultur. ${ }^{11}$ Nordisk rettsenhet er særlig relevant for spørsmålet om ansvar pga. felles nordiske skadeerstatningslover. Verken Finland eller Danmark har imidlertid utskytningsanlegg, og utvalget så derfor også behov for å se hen til lovgivningen særlig i Frankrike ${ }^{12}$ som har dette.

9 http://www.unoosa.org/pdf/limited/c2/AC105_C2_2013_CRP06E.pdf . Modellen er utviklet av Committe on the Peaceful Uses of Outer Space i April 2013

10 Dansk Lov om aktiviteter i det ydre rum, dansk RL, https://www.retsinformation.dk/Forms/R0710.aspx?id=180047, Finlands Act on Space Activities(63/2018), finsk RL, https://tem.fi/documents/1410877/3227301/Act+on+Space+Activities/a3f9c6c9-18fd4504-8ea9-bff1986fff28/Act+on+Space+Activities.pdf

11 Rett i bane s. 33.

12 Fransk LOI no 2008-518 du 3 juin 2008 relative aux opérations spatiales, fransk RL, https://download.esa.int/docs/ECSL/France.pdf 
I denne artikkelen er det en noe bredere komparativ tilnærming. Dette har sammenheng med departementets fokusering på næringsutvikling i Norge. Romindustrien er internasjonal, og det er et viktig hensyn at norsk industri har like konkurransevilkår som romindustri i andre land. Hvis andre land gir industrien bedre ansvarsvilkår enn Norge risikerer Norge dels at norske aktører foretrekker oppskytning i utlandet, dels at utenlandske aktører finner utskytning fra Andøya uinteressant. Det er derfor et sentralt poeng å unders $\varnothing$ ke om norske regler er konkurransedyktige i et internasjonalt perspektiv. I forlengelsen av dette anbefaler Sofia modellen harmonisering særlig av reglene om ansvarsbegrensning og krav til forsikringssum for å unngå «forum shopping». ${ }^{13}$ Fremstillingen er likevel begrenset til en del europeiske land med lignende rett systemer som de nordiske. ${ }^{14}$ Den anglo amerikanske lovgivningsteknikken er vesentlig forskjellig fra den nordiske og mellom-europeiske og derfor mindre egnet i en slik analyse.

\section{Norges internasjonale ansvar for romaktivitet}

\subsection{Problemstilling og utgangspunkter}

Hensikten her er først og fremst å gi en oversikt over Norges internasjonale erstatningsansvar for skade voldt av romgjenstand som bakgrunn for utvalgets forslag og vurderinger. Det er imidlertid uenighet internasjonalt om hvor langt dette ansvaret går. Dette har betydning både for Norges erstatningsansvar for oppskytninger som skjer utenfor Norge og for andre traktatparters erstatningsansvar om de deltar i oppskytning i Norge. Diskusjonen har også betydning for forholdet mellom utkastets regler om regress og direkte erstatningsansvar. Det er derfor hensiktsmessig å gå noe mer detaljert inn i dette spørsmålet, se kap. 3.4.2 nedenfor.

Utgangspunktet for tolkning av internasjonale traktater og konvensjoner er alminnelige folkerettslige regler om traktattolkning slik de er kodifisert i Wien-konvensjonen om

13 Sofia modellens kommentar til art. $12 \mathrm{nr} .1 \mathrm{om}$ forsikringssum.

$14 \quad$ Svensk Lag (1982:963) om rymdverksamhet, svensk RL https://www.riksdagen.se/sv/dokument-lagar/dokument/svensk-forfattningssamling/lag1982963-om-rymdverksamhet_sfs-1982-963,

Austrian Federal Law on the Authorisation of Space Activities and the Establishment of a National Space Registry (Austrian Outer Space Act, adopted by the National Council on 6 December 2011, entered into force on 28 December 2011), Østerisk RL, http://www.unoosa.org/documents/pdf/spacelaw/national/austria/austrian-outer-spaceactE.pdf,

Belgisk Law of 17 September 2005 on the Activities of Launching, Flight Operation or Guidance of Space Objects, belgisk RL, https://www.belspo.be/belspo/space/doc/beLaw/Loi_en.pdf,

Nederland Rules Concerning Space Activities and the Establishment of a Registry of Space Objects (Space Activities Act), (13.06.06), nederlandsk RL, http://www.unoosa.org/oosa/en/ourwork/spacelaw/nationalspacelaw/netherlands/space ac $\underline{\text { tivities actE.html, }}$ 
traktatretten artikkel 31-33. ${ }^{15}$ Ifølge art. $31 \mathrm{nr} .1$ skal traktater be "interpreted in good faith in accordance with the ordinary meaning to be given to the terms of the treaty in their context and in the light of its object and purpose". Det følger videre av art. $31 \mathrm{nr} .3$ (b) at man i tillegg til konteksten skal ta hensyn til "any subsequent practice in the application of the treaty which establishes the agreement of the parties regarding its interpretation."

\subsection{Statens ansvar etter Romtraktaten og Ansvarskonvensjonen ${ }^{16}$}

Traktat om det ytre rom av 27. januar $1967^{17}$ pålegger traktatpartene en folkerettslig «responsibility» for eget lands aktivitet i rommet, på månen og andre himmellegemer, uansett om aktiviteten utøves av staten eller private. ${ }^{18}$ Statens erstatningsansvar er regulert i art. VII:

Each State Party to the Treaty that launches or procures the launching of an object into outer space, including the moon and other celestial bodies, and each State Party from whose territory or facility an object is launched, is internationally liable for damage to another State Party to the Treaty or to its natural or juridical persons by such object or its component parts on the Earth, in air or in outer space, including the moon and other celestial bodies.

Bestemmelsen fastsetter at enhver statlig traktatpart er «internationally liable» for skade påført en annen traktatpart såfremt (i) staten «launches or procures the launching» eller utskytning skjer fra statens territorium eller et anlegg underlagt statens jurisdiksjon, og (ii) skaden rammer en annen traktatpart eller «its natural or juridicial persons». I så fall omfatter ansvaret skade på jorden, i luften og i det ytre rom.

Ansvaret er videre utdypet i Ansvarskonvensjonen 29. mars $1972,{ }^{19}$ hvor art II sier at:

A launching State shall be absolutely liable to pay compensation for damage caused by its space object on the surface of the earth or to aircraft flight.

Bestemmelsen fastsetter et objektivt ansvar for skade voldt av romgjenstand såfremt skaden rammer jordoverflaten eller fly under flygning. Ifølge art. VI er det unntak fra det objektive ansvaret såfremt «a launching State establishes that the damage has resulted either wholly or partially from gross negligence or from an act or omission done with intent to cause damage on the part of a claimant State or of natural or juridical persons it represents» (nr. 1). Dette

15 Vienna Convention on the Law of Treaties, Vienna, 23 May 1969

http://www.admiraltylawguide.com/conven/lawoftreaties1969.html.

16 Kapittel 3.2 er i hovedsak sammenfallende med Rett i bane kap.13.2, som bygger på utkastet til denne artikkelen, se henvisning note 116 .

17 http://www.unoosa.org/oosa/en/ourwork/spacelaw/treaties/outerspacetreaty.html Traktaten ble ratifisert av Norge i 1969 og er i dag ratifisert av 109 land, jf. Rett i bane s. 22.

18 Art. VI.

19 http://www.unoosa.org/oosa/en/ourwork/spacelaw/treaties/liability-convention.html. Konvensjonen ble ratifisert av Norge i 1995 og er i dag ratifisert av 96 land, se Rett i bane s. 23. 
gjelder likevel ikke hvor skaden er en følge av aktivitet som ikke er i samsvar med internasjonal lov (nr. 2).

Ifølge art. III er «launching State» også ansvarlig for skade på annet lands romobjekt og personer om bord i slike som ikke skjer på jordoverflaten såfremt skaden «is due to its fault or the fault of persons for whom it is responsible». Videre følger det av art. VII at konvensjonens ansvarsregler ikke gjelder skade forårsaket av oppskytende stat som rammer

(a) nationals of that launching State;

(b) foreign nationals during such time as they are participating in the operation of that space object from the time of its launching or at any stage thereafter until its descent, or during such time as they are in the immediate vicinity of a planned launching or recovery area as the result of an invitation by that launching State.

Oppskytende stat har derfor ikke ansvar for skade som rammer egne borgere/selskaper, og heller ikke skade som rammer andre lands «nationals» under felles oppskytningsoperasjoner. Unntaket for skade på egne borgere/selskaper er i samsvar med generelle internasjonale rettsprinsipper om at dette skal reguleres på nasjonalt og ikke internasjonalt nivå. ${ }^{20}$

Begrepene «skade» og «launching State» er definert i art. I (a) og (c):

(a) The term "damage" means loss of life, personal injury or other impairment of health; or loss of or damage to property of States or of persons, natural or juridical, or property of international intergovernmental organizations;

(c) The term "launching State" means:

(i) A State which launches or procures the launching of a space object;

(ii) A State from whose territory or facility a space object is launched;

Det følger videre av art. I (b) at formuleringen «launching» inkluderer «attempted launching», slik at ansvaret omfatter skader ved mislykket utskytning. Konvensjonen inneholder ingen definisjon av begrepene «launching» eller «procures».

Det følger altså av både Romtraktaten og Ansvarskonvensjonen at staten er ansvarlig for skader påført av romgjenstander såfremt staten enten selv skyter opp eller forestår oppskytning av gjenstanden, eller oppskytning skjer fra statens territorium eller anlegg. Det siste alternativet er det enkleste og gjennomgås derfor først i kap. 3.3. Deretter omtales ansvaret for en stat som skyter opp eller forestår oppskytning, herunder spørsmålet om dette alternativet inkluderer oppskytning foretatt eller bestilt av private personer eller selskaper i punkt 3.4.

\subsection{Ansvar for oppskytning fra norsk territorium eller anlegg}

20 Cologne Commentary on Space Law Volume 1 Outer Space, 2009, s. 135. 
Art I (c) sier at «A State from whose territory or facility a space object is launched» regnes som oppskytende stat. Statens ansvar er knyttet til stedet der oppskytningen foretas og gjelder derfor uansett hvem som foretar oppskytningen. Selve oppskytningen foretas normalt av raketteieren. Staten er derfor ansvarlig hvis staten som raketteier forestår oppskytning fra eget territorium eller anlegg, og hvis raketten eies/skytes ut av norske statsborgere eller selskaper registrert i Norge. Bestemmelsen gjelder imidlertid også såfremt en annen stat B eller B's statsborgere eller selskaper foretar oppskytning fra et norsk anlegg. Hvis B foretar oppskytning i Norge, følger det av art. I (c) (i) at også B er ansvarlig. Hvor langt dette ansvaret for $\varnothing$ vrig rekker drøftes i 3.4 nedenfor.

Territorium må i denne sammenheng forstås med utgangspunkt i alminnelig folkerett. Det dekker dermed statens landterritorium i tillegg til indre farvann og territorialfarvann. ${ }^{21}$ For Norges del omfatter dette oppskytninger fra basen på Andøya, og andre oppskytninger enten fra fastlands-Norge, Svalbard, Jan-Mayen eller bilandene, i tillegg til norske havområder langs kysten. Ansvaret er knyttet til territoriet eller anlegg. Det er naturlig å forstå dette slik at anlegg kan ligge utenfor territoriet såfremt staten har jurisdiksjon over anlegget. Slike anlegg kan også være plassert på skip, boreplattformer eller luftfartøy som er registrert i et norsk register. Det spiller da ingen rolle for Norges ansvar hvor i verden oppskytningen skjer.

\subsection{Ansvar for den stat som skyter opp eller anskaffer oppskytning ${ }^{22}$}

\subsubsection{Begrepene skyter opp eller anskaffer}

Konvensjonene omfatter også stater som skyter opp romgjenstander og stater som anskaffer oppskytning («procures launching»). Hvis en stat skyter opp romgjenstander fra eget territorium faller de to alternativene art. I (c) (i) og (ii) sammen. Art. I (c) (i) får derimot selvstendig betydning hvor en stat skyter opp en romgjenstand på annen stats territorium eller anlegg.

Ordet «launches» omfatter de tilfeller hvor staten som eier av raketten selv skyter den opp fra utenlandsk territorium. Det er større tvil knyttet til forståelsen av ordet «procures», men formuleringen betyr antagelig at staten bestiller eller avtaler rett til å bruke et oppskytningsanlegg på en annen stats territorium eller anlegg. ${ }^{23}$ En slik fremgangsmåte er vanlig i dagens romaktivitet. Det er mange land som ikke har egne oppskytningsanlegg og som derfor er avhengig av å bruke slike anlegg i andre land. Stater med oppskytningsanlegg kan sende ut raketter hvor det er plass til mange små satellitter eller såkalt «nyttelast» slik at andre land kan bestille «plass» for sin satellitt i en felles oppskytning. Nasjonale anlegg kan

21 De forente nasjoners havrettskonvensjon 10-12-1982, artikkel 2.

22 En del synspunkter her er publisert i Rett i bane kap. 5.3 men med et annet opplegg.

23 Se nærmere Rett i bane s. 27-28. 
også tilby oppskytning for utenlandske raketter. Den staten som bestiller oppskytning av rakett eller plass i en rakett må da regnes som «launching State» etter dette alternativet. Etter omstendighetene kan man derfor ha flere «launching States».

Ansvarssubjektet i bestemmelsen er «staten». Spørsmålet er derfor hvem staten i dette tilfellet må identifiseres med. Hvis statens romaktivitet er organisert slik at den utøves av et statlig selskap er det rimelig klart at staten må identifiseres med dette selskapet. Spørsmålet blir vanskeligere hvor oppskytningen gjøres av et privat selskap. Det er anført i litteraturen at det avgjørende er om oppskytningen skjer på vegne av staten eller er foretatt i statens interesser, slik at staten har fordel av oppskytningen, ${ }^{24}$ men spørsmålet må regnes som usikkert.

\subsubsection{Statens ansvar for private aktører}

I motsetning til art. I (c) (ii), som gjør staten ansvarlig for oppskytninger fra territoriet eller anlegg uavhengig av hvem som skyter opp, gjelder (i) for en «State which launches ...». Ordlyden angir staten som det handlende subjektet og taler isolert sett for at staten ikke er ansvarlig for private aktører som foretar eller bestiller oppskytning fra anlegg i andre land.

Ansvarskonvensjonen art. VII sondrer mellom «launching State» og «nationals» i reglene om unntak for statens ansvar, men konvensjonen opererer ikke med noe generelt skille mellom statlige og ikke-statlige romaktiviteter. Ansvarskonvensjonens regler bygger imidlertid på Romtraktatens artikkel VI, som har et tydeligere skille mellom aktiviteter som gjøres av staten selv og private. Etter Romtraktatens art. VI har traktatparten «international responsibility for national activities in outer space ... whether such activities are carried on by governmental agencies or by non-governmental entities». Kravet om tilsyn er videre begrenset til «The activities of non-governmental entities in outer space, including the moon and other celestial bodies». Romtraktatens art. VII sier dessuten at erstatningsansvaret overfor en annen stat også gjelder for «its natural or juridical persons». Når man her sondrer mellom staten og private, er det vanskelig å se at formuleringen «State» i den etterfølgende Ansvarskonvensjonen skal inkludere private uten at dette sies uttrykkelig.

Ordlyden og konteksten tilsier derfor at Norge ikke har ansvar for norske statsborgere eller selskaper som bestiller eller organiserer oppskytning fra oppskytningsanlegg på annet lands territorium eller fra annet lands anlegg. Dette betyr ikke at det ikke er noe ansvarssubjekt; Den stat hvis territorium eller anlegg det skytes opp fra, vil være ansvarssubjekt etter Ansvarskonvensjonen art I (c) (ii). Men det blir ikke noe solidaransvar for den stat hvor oppskytende aktør er hjemmehørende. Selskaper fra en annen stat B som skyter opp fra Norge vil i så fall heller ikke pådra $\mathrm{B}$ noe ansvar etter konvensjonen.

24 Stephen Hobe, Space Law, 2019 (Hobe (2019)), s. 80. 
Ser man ordlyden og språkbruken i konvensjonene i sammenheng med utviklingen i internasjonal romaktivitet etter at Ansvarskonvensjonen ble skrevet, blir løsningen likevel mindre opplagt. ${ }^{25}$ På 1960/70-tallet var det stater som drev med romfart. Utviklingen har ført til at private parter har begynt med oppskytning både i eget hjemland og i andre land. Spørsmålet er da om denne utviklingen tilsier at begrepet «oppskytende stat» må tolkes slik at stater også hefter for sine borgeres handlinger utenfor eget territorium.

I den utstrekning man har en traktatpart som territorium stat, er det vanskelig å se at en slik utvikling har noen betydning. I utgangspunktet må det være nok for skadelidte å kunne holde seg til en traktatpart. Ut fra formålet med reguleringen slik den følger av fortalen til Ansvarskonvensjonen synes det sentrale nettopp å være at skaden skal tilordnes den staten som er involvert i oppskytningen for å sikre full og rask erstatning til de skadelidte. ${ }^{26}$ Selv om konvensjonen legger opp til to (eller flere) mulige ansvarssubjekter, synes den ikke å forutsette at det er nødvendig med flere ansvarssubjekter for å sikre skadelidtes interesse i dekning for sitt tap. Ser man de to ansvarsalternativene i sammenheng med utviklingen er det mer naturlig å legge til grunn at formålet er ansvarsfordeling mellom statene som er involvert i oppskytningen. Det er få stater som har anlegg for oppskytning på eget territorium, og det er lite rimelig om disse statene skulle være eneansvarlig når andre stater bruker deres oppskytningsanlegg. Hensynet til en rimelig ansvarsfordeling mellom involverte stater tilsier imidlertid ikke mer enn at staten er ansvarlig i den grad staten selv er involvert i oppskytningen. Ved privat deltagelse, bør ansvaret legges der.

Har man derimot ikke en traktatpart som territorium stat, faller det objektive ansvarsgrunnlaget for territorium staten bort. Hvis oppskytning i så fall bestilles av en privat part, får man heller ikke noe ansvarsgrunnlag for oppskytende stat, og skadelidte står uten dekning. I litteraturen er det anført at hvis man her ikke lar staten hvor den private kjøperen av oppskytningstjenester er hjemmehørende være ansvarlig, vil dette føre til at «the very basis of the liability system would be destroyed» fordi man ikke har noen som er ansvarlig. ${ }^{27}$ Men en slik situasjon vil oppstå også hvis den som bestiller oppskytning er hjemmehørende i en stat som ikke er traktatpart. Det er vanskelig å se at deltagelse av stater som ikke er part i traktaten skal føre til utvidelse av ansvaret for de som er part.

I forlengelsen av reparasjonshensynet overfor skadelidte er det også anført at hvor flere stater er involvert skal skadelidte «not suffer from possible unclarities or difficulties of proof» og at «any of the launching States involved can be sued according to the preference of the

25 Utviklingen er beskrevet i Hobe, 2019, s. 29 f., se også Cologne Commentary on Space Law Volume 1 Outer Space Treaty, 2009, s. 6 f.

26 Fortalen til Ansvarskonvensjonen 4 og 5 ledd.

27 Armel Kerrest, Liability for Damage Caused by Space Activities, in M. Benkö and K-U Schrogl (eds), Space Law, Current Problems and Perspectives for Future Regulation, Utrect 2005, s. 91 f. (Kerrest), på s. 94. 
victim». ${ }^{28}$ Når ansvaret er objektivt er det vanskelig å se at bevisspørsmål skal begrunne flere ansvarssubjekter.

Også i forhold til ansvarsbestemmelsen i Romtraktaten art. VII, som er utgangspunktet for Ansvarskonvensjonen, har det vært hevdet at traktatparten har ansvar for private som bestiller oppskytning i annen stat. Med referanse til det alminnelige folkerettslige prinsippet om statens «inherent jurisdiction over its territory and nationals» ${ }^{29}$ anføres at det objektive ansvaret for en «launching state» gjelder uavhengig av om aktiviteten er «public or private». Referansen gjelder imidlertid «The nationality principle» som grunnlag for strafferettslig jurisdiksjon, og det er vanskelig å se at dette er avgjørende for erstatningsrettslig jurisdiksjon på objektivt grunnlag.

Det er også anført at en slik tolkning følger av forholdet mellom art. VI og VII i Romkonvensjonen. ${ }^{30}$ Ifølge art. VI har traktatparten "international responsibility for national activities in outer space, ... whether such activities are carried on by governmental agencies or by non-governmental entities”. Samtidig er det anført at «responsibility» og «liability» refererer til hhv. tilsyn og kontroll og erstatningsansvar, og derfor regulerer to forskjellige forhold.$^{31}$ Det er ikke gitt at tilsyn og kontroll med egne borgere også skal påføre staten erstatningsansvar på objektivt grunnlag for disse borgernes handlinger. At staten evt. kan få et skyldansvar for manglende tilsyn, er noe annet.

Videre vises det til nåværende lovgivning i stater som driver med romaktivitet hvor flere stater registrerer satellitter skutt opp av nasjonale selskaper på annet lands territorium. ${ }^{32}$ Dette gjelder tolkning av begrepet «launching State» i Registreringskonvensjonen, hvor art. II nr. 1 sier at "launching State" har plikt til å registrere en romgjenstand som «is launched into earth orbit or beyond”. Definisjonen av begrepet «launching State» i art. I (a) er identisk med definisjonen i Ansvarskonvensjonen og tilsier i utgangspunktet at det er samsvar mellom registreringsstat og ansvarssubjekt. Et argument for en slik løsning er at det normalt er registreringsstaten som fører tilsyn og som derfor kan påvirke risikoen for skade gjennom krav til forebyggende tiltak.

28 Hobe (2019) s. 80-81. Det er uklart om dette kun gjelder situasjoner hvor oppskytningen foretas at statlige selskaper el.l. eller om det gjelder private selskaper uten offentlig tilknytning

29 Cologne Commentary on Space Law Volume 1 Outer Space Treaty, 2009 s . 128 og note 6 med henvisning til Brownlies's Principles of Public international law, 6 utgave, 2003, s.301 f, se også 8. utgave 2012 s. 459 f.

30 Cologne Commentary on Space Law Volume 1 Outer Space Treaty, 2009 s. 135, Bin Cheng, International Responsibility and Liability for Launch Activities, Air \& Space Law, Vol. XX 1995, 297 f. på s. 306-307, Kerrest s. 94.

31 Cologne Commentary on Space Law Volume 1 Outer Space Treaty, 2009 s. 128-129.

32 Cologne Commentary on Space Law Volume 1 Outer Space Treaty, 2009 s. 138, Kerrest, s. 93-94. 
På den annen side har Registreringskonvensjonen regler som avviker fra dette utgangspunktet. For det første sier Registreringskonvensjonen art. II nr. 2 at hvor det er to eller flere launching States skal disse «jointly determine which one of them shall register the object in accordance with paragraph 1 of this article». Dette betyr at ved oppskytning fra fremmed territorium eller anlegg, må de involverte statene bli enige om en registreringsstat. Hvis dette er territorium staten, vil registrering og ansvar falle sammen. Hvis ansvar pålegges satellitteier staten får man i så fall et ansvarssubjekt uten registreringsplikt og tilsyn og begrepet «launching State» blir forskjellig i de to konvensjonene. Hvis det er satellitteierstaten som registrerer, vil dette ikke frata territorium staten ansvar. Enkelte land åpner ikke for registrering av utenlandske romgjenstander som skytes opp fra deres territorium eller anlegg, og det er visstnok i praksis vanlig at satellitter registreres i den staten hvor satellitt-eier er hjemmehørende. Territorium staten beholder likevel ansvaret, og det blir ikke samsvar mellom registreringsstat og ansvarssubjekt med mindre man forutsetter at registreringsstat alltid skal være ansvarssubjekt.

For det andre gjelder plikten til registrering kun romgjenstander i det ytre rom/i banen. Man kan derfor få en situasjon hvor en romgjenstand volder skade uten at den er registrert i et nasjonalt register, for eksempel ved eksplosjon under oppskytning. I dette tilfellet vil det ikke være noen registreringsstat som kan være ansvarssubjekt.

Det er derfor ikke lett å se at statspraksis knyttet til registrering skal være avgjørende for tolkning av Ansvarskonvensjonen. Argumentasjonen for at en stat skal være oppskytende stat for sine private aktører som skyter opp på anlegg i utlandet fremstår samlet ikke som overbevisende, men ut fra den internasjonale diskusjonen er spørsmålet tvilsomt. Et spørsmål i det følgende er derfor hvilken betydning dette kan ha for den nasjonale reguleringen.

\section{Konvensjonsansvaret og nasjonal regulering - jurisdiksjon og lovvalg}

Det følger av fremstillingen over at staten Norge som «launching state» har objektivt ansvar for skader voldt av romgjenstand på jordoverflaten eller fly under flygning, men at ansvaret ikke omfatter skade på egne «nationals» og heller ikke skade på deltagere i samme utskytningsoperasjon. Videre er Norge ansvarlig for skade på romgjenstand forårsaket andre steder enn på jordoverflaten eller på personer/gjenstander om bord i denne romgjenstanden hvis skaden skyldes feil fra staten eller noen staten hefter for.

Romtraktaten og Ansvarskonvensjonen gjelder forholdet mellom de stater som er part i dem og Ansvarskonvensjonen forutsetter at erstatningskrav løses gjennom diplomatiske kanaler. ${ }^{33}$

33 Se Sofia-modellen art. 11 Comment s. 8, som også anbefaler "the New Rules for Arbitration of Disputes relating to Outer Space Activities adopted in 2011 by the Permanent Court of Arbitration." 
Disse reglene kan derfor ikke påberopes direkte av skadelidte overfor oppskytende stat som skadevolder, og sier heller ingenting om ansvaret for andre aktører enn staten. Dette må reguleres i nasjonal lovgivning ved regler om ansvar og regress. For slik nasjonal lovgivning gjelder alminnelige regler om jurisdiksjon og lovvalg. Skader på norsk territorium og norske anlegg voldt av romgjenstander skutt ut i Norge er utenfor Norges konvensjonsansvar. Ansvar for slike skader kan reguleres gjennom norske erstatningsregler. Men hvis romgjenstander skutt ut i Norge volder skade på en annen traktatstats territorium er det spørsmål hvor langt norske regler kan gjøres gjeldende. Dette gjelder både det objektive ansvaret for operatøren og regressansvaret for operatøren om den norske stat dekker kravet etter Ansvarskonvensjonen. Det samme gjelder om norsk romgjenstand som skytes ut i en annen traktat stat volder skade under utskytning, drift, eller retur, eller hvor en norsk romgjenstand kolliderer med skip, luftfartøy eller romgjenstand tilhørende en annen traktatstat $\mathrm{i}$ hhv. internasjonalt farvann, luftrom eller verdensrommet.

Etter tvisteloven ${ }^{34} \S 4-4$ (1) kan søksmål reises ved saksøktes alminnelige verneting. Tvisteloven § 4-5 (3) sier videre at erstatningskrav utenfor kontraktsforhold kan reises på det sted skaden oppstod eller der skadevirkningen inntraff eller vil kunne inntre. Det samme gjelder søksmål mot forsikringsgiver om dekning for slik skade. Utgangspunktet i Luganokonvensjonen ${ }^{35}$ art. 2 er at personer med bosted i en konvensjonsstat uansett statsborgerskap kan saksøkes ved domstolene i bostedslandet. Etter art. 5 nr. 3 kan en person som har bosted i en konvensjonsstat i saker om erstatning utenfor kontraktsforhold velge å reise kravet ved domstolen for det sted der skaden ble voldt eller oppsto, eller der det kan komme til å skje, såfremt dette er i en annen konvensjonsstat. Et direkte krav mot skadevolderens ansvarsforsikring kan ifølge art. 11 nr. 2 jf. art. 9 nr. 1 a) og art. 10 anlegges ved domstolene på forsikringsgiverens bosted eller ved domstolene på skadestedet såfremt «slike direkte søksmål er tillatt».

Hvis søksmålet blir reist i Norge, gjelder norske lovvalgsregler. Norge har ingen generell lovregulering av spørsmålet om lovvalg for erstatningsrettslige krav, men to nyere høyesterettsdommer ${ }^{36}$ inneholder klare uttalelser om at skadestedets rett skal anvendes i internasjonale erstatningsrettslige saker. Dette sammenfaller med Roma II forordningen ${ }^{37}$ artikkel 4, som i henhold til disse dommene skal tillegges vekt også i norsk internasjonal privatrett, ${ }^{38}$ såfremt det ikke finnes en klar norsk lovvalgsregel. I utkast til lov om lovvalg for

\footnotetext{
Lov-205-06-17-90 Tvisteloven

Konvensjon om domsmyndighet og om anerkjennelse og fullbyrdelse av dommer i sivile og kommersielles saker 30-10-2007.

36 Rt. 2009 s. 1537 «Bokhandler» og Rt. 2011 s. 531 «Krigsforbryter».

37 Europa-Parlamentets og Rådets forordning (EF) nr. 864/2007, af 11. juli 2007 om lovvalgsregler for forpligtelser uden for kontrakt (Rom II-forordningen).

38 Cordero-Moss Utredning om formuerettslige lovvalgsregler, https://www.regjeringen.no/contentassets/aa11d98c5c144dac8361c7af7677f303/enperson utredningen-om-formuerettslige-lovvalgsregler.pdf (Utredning) s.117, se også Guiditta Cordero-Moss, Internasjonal privatrett på formuesrettens område, Oslo 2013 s. 327.
} 
forpliktelser som springer ut av kontrakt og for forpliktelser utenfor kontrakt er $\S 15$ utformet i tråd med artikkel 4 i Roma II: ${ }^{39}$

En forpliktelse utenfor kontrakt som springer ut av skadevoldende handling er underlagt retten i staten der skaden inntrer, uten hensyn til stedet der den skadevoldende handling ble begått eller stedet der indirekte skade oppstår, med mindre noe annet er fastsatt i denne loven.

Dersom skadelidte og skadevolderen ved skadetidspunktet har sitt vanlige bosted i samme stat, anvendes retten i denne staten.

Fremgår det klart av alle sakens omstendigheter at den skadevoldende handling åpenbart har nærmere tilknytning til en annen stat enn den som utpekes av lovvalgsreglene i første og annet ledd, anvendes retten i denne staten. En åpenbart nærmere tilknytning til en annen stat kan bero på den omstendighet at det finnes et forutgående rettsforhold mellom partene med nær tilknytning til den skadevoldende handling, for eksempel en kontrakt.

Ved skade voldt av en romgjenstand skutt ut i Norge på skadelidte i en annen traktatstat, B, er utgangspunktet etter lovvalgutkastet $\S 15$ første ledd at ansvaret skal bedømmes etter skadestedets rett. Dette gjelder også i tilfeller hvor den skadevoldende handling ble begått i Norge. ${ }^{40}$ En skadelidt i B kan i så fall ikke påberope seg et objektivt ansvar for operatøren etter norske regler. Lovvalgforslaget $\S 15$ annet ledd er ikke relevant i denne situasjonen. Spørsmålet blir da om tredje ledd kan føre til et annet resultat. Dette forutsetter «at den skadevoldende handling åpenbart har nærmere tilknytning til en annen stat». Et argument for tilknytning til Norge er at den skadevoldende handlingen forutsetningsvis er underlagt norske regler om tillatelse og tilsyn, mens det vil være helt tilfeldig hvor en romgjenstand faller ned. Ifølge Roma II artikkel 17 kan handlingsnormer på skadestedet imidlertid være relevant selv om man bedømmer erstatningsspørsmålet ut fra skadestedets rett, ${ }^{41}$ og en slik regel er foreslått i utkastet $\S 28 .{ }^{42}$ Dette behøver derfor ikke være avgjørende for lovvalget.

Bestemmelsen i tredje ledd sier videre at «En åpenbart nærmere tilknytning til en annen stat kan bero på den omstendighet at det finnes et forutgående rettsforhold mellom partene med nær tilknytning til den skadevoldende handling, for eksempel en kontrakt». Hvis skadelidte fra B deltar i samme utskytningsoperasjon vil det normalt være en slik kontrakt som da også kan bli avgjørende for lovvalget, men det er lite sannsynlig at skaden da skjer i B hvis utskytningen skjer i Norge. Derimot vil det ikke være noen kontrakt mellom skadevolder og en tilfeldig skadelidt i B. På den annen side vil det foreligge en folkerettslig bindende avtale mellom Norge og B. Dette kan tale for at domstolene skal anvende norske erstatningsregler, men lovvalget i denne situasjonen fremstår som usikker.

\footnotetext{
39 Utredning s. 193.

$40 \quad$ Se Utredning s. 121-122.

41 Utredning s. 122.

$42 \quad$ Utredning s. 198-199.
} 
Hvis traktatstat B velger å påberope seg Ansvarskonvensjonen mot Norge, foreslår utkastet at staten i neste omgang kan kreve regress hos operatøren. Etter sin ordlyd gjelder lovvalgutkastet $\S 15$ første ledd enhver «forpliktelse utenfor kontrakt som springer ut av skadevoldende handling», og mye taler for at utgangspunktet også i dette tilfellet er skadestedets rett. Annet ledd sier imidlertid at «Dersom skadelidte og skadevolderen ved skadetidspunktet har sitt vanlige bosted i samme stat, anvendes retten i denne staten». Bestemmelsen er ikke direkte anvendelig på forholdet mellom en regresskreditor og en regressdebitor og staten har ikke noe «vanlig bosted». Det kan imidlertid anføres at staten ved å erstatte skadelidtes tap har trådt inn i skadelidtes posisjon mot skadevolder, og at annet ledd derfor må komme til anvendelse. Det kan også anføres at samme løsning må følge av tredje ledd om «at den skadevoldende handling åpenbart har nærmere tilknytning til en annen stat» og «at det finnes et forutgående rettsforhold mellom partene med nær tilknytning til den skadevoldende handling, for eksempel en kontrakt». Operatøren opererer her under en norsk tillatelse hvor forutsetningen er at staten skal holdes skadesløs for evt. utbetalinger staten har hatt. Det ville representere en helt tilfeldig fordel for operatøren om han skulle slippe dette ansvaret fordi skadestedets rett ikke har tilsvarende regress regler. De beste grunner taler derfor etter min mening for at man anvender norsk erstatningsrett i denne situasjonen, men løsningen fremstår også her som usikker.

Ved kollisjon mellom norskregistrert romgjenstand skutt ut i Norge, og skip eller luftfartøy hjemmehørende i en annen traktaturstat B i internasjonalt farvann/luftrom skjer skaden utenfor traktatstatens territorium. Et naturlig utgangspunkt er da å bruke registreringsstatens rett. I så fall må spørsmålet om jurisdiksjon og lovvalg løses etter samme linjer som ovenfor.

Hvis romgjenstand registrert $\mathrm{i}$ annen traktatstat enn Norge skytes ut fra Norge vil Norge verken være bosted for skadevolder eller skadested, men Norge er fremdeles ansvarlig som oppskytende stat. Som nevnt foran i kap. 3.4.2 er det usikkert om også den andre traktastaten i så fall er ansvarlig som oppskytende stat. Hvis Norge betaler i henhold til Ansvarskonvensjonen, er det usikkert om Norge kan påberope norske erstatningsregler som grunnlag for regress mot den utenlandske operatøren. Ved oppskytning på Andøya av raketter og nyttelast registrert i andre traktatstater bør derfor spørsmål om ansvar og regress løses i tillatelsen.

Den norske staten eller en norsk operatør kan også volde skade ved utskytning i annen traktatstat, f.eks. det franske anlegget Guiana Space Center. Hvis skadelidte reiser søksmål i Norge kommer de norske lovvalgsreglene til anvendelse, men vurderingene etter utkastet $\S 15$ tredje ledd vil avhenge av om den aktuelle romgjenstanden er registrert $\mathrm{i}$ utskytningslandet eller Norge, evt. i en tredje stat.

Det norske lovvalgforslaget bygger som nevnt på Roma II forordningen og vil derfor gjelde som utgangspunkt for lovvalget innenfor EU hvis skaden skjer og sak reises der. 
Ansvarskonvensjonen er ratifisert av 98 land og mange stater utenfor EU-området, og en romgjenstand kan volde skade hvor som helst. Hvilket lovvalg som i så fall vil gjelde vil avhenge av hvor søksmål om erstatning reises og hvilke lovvalgsregler som gjelder der.

Usikkerheten knyttet til jurisdiksjon og lovvalg i disse sakene viser betydningen av Sofiamodellen og behovet for harmonisering av reglene om ansvar og regress. Harmonisering av ansvarsreglene vil beskytte skadelidte som rammes av skade fra en romgjenstand, i tråd med sentrale hensyn i Ansvarskonvensjonen. Harmonisering av regressreglene vil beskytte staten mot å bli sittende med et ansvar som forutsetningsvis skal dekkes av den som driver aktiviteten. Staten kan også sikre seg rett til regress som vilkår i tillatelsen.

\section{Utkastets regler om ansvar}

\subsection{Ansvarssubjekt}

Utvalget foreslår at ansvaret for skader voldt av romgjenstand som er regulert i loven knyttes til operatøren. ${ }^{43}$ Operatøren er i utkastet $\S 3$ definert som «alle som driver med romaktivitet», og det er operatøren som søker tillatelse etter kapittel 2 og er pliktsubjekt for alle lovens plikter. Begrepet har ikke noe motstykke i konvensjonene fordi disse er rettet mot statene som «launching State». Bruken av operatør som ansvarssubjekt er i samsvar med Sofia-modellen og de nasjonale reglene omtalt her. ${ }^{44}$ De anvendte definisjonene er i hovedsak lik utkastet, ${ }^{45}$ men noen definisjoner inkluderer de som har til hensikt å drive ${ }^{46}$ og de som er «effectively responsible» for aktiviteten. ${ }^{47} \mathrm{I}$ disse reglene er operatøren normalt også pliktsubjekt for reglene om tillatelse og tilsyn og omtales i enkelte lover som lisenshaver. ${ }^{48}$

Utvalgets utgangspunkt er at det er naturlig at ansvarsreguleringen og reglene om tillatelse kobles sammen. ${ }^{49}$ Den som har tillatelsen har den $\varnothing$ konomiske interessen i virksomheten. Driften av virksomheten vil være basert på en kost/nytte vurdering med en forventning om $\varnothing$ konomisk gevinst. Både rimelighetshensyn og hensynet til økonomisk effektivitet tilsier at kostnadene ved skadene tilordnes den part som har den økonomiske interessen i virksomheten. ${ }^{50}$ Hensynet til $\varnothing$ konomisk effektivitet er i samsvar med hensynet til fremtidig

43 Utkastet kapittel 13 om Ansvar og forsikring.

44 Sofia-modellen $\S 11 \mathrm{nr}$. 1, finsk RL $\S 7$, dansk RL $\S 15$, østerisk RL $\S 11$, belgisk RL art. 15, fransk RL art. 13.

45 Sofia-modellen $\S 2$ c), Finsk RL $\S 4$ nr. 3, dansk RL $\S 4$ nr. 3, østerisk RL $\S 2$ nr. 3, Belgisk RL art. $3 \mathrm{nr}$ 2, fransk RL art. $1 \mathrm{nr} .2$.

46 Finsk RL $\S 4$ nr. 3, dansk RL $\S 4$ nr. 3, østerisk RL $\S 2$ nr. 3, belgisk RL art. 3 nr. 2.

$47 \quad$ Finsk RL $\$ 4$ nr. 3

$48 \quad$ Nederlandsk RL sec. 12 nr. 2, svensk RL $6 \S$.

49 Se til dette Rett i bane s. 104-105.

50 Se Trine-Lise Wilhelmsen og Birgitte Hagland, Om erstatningsrett, 2017 (Wilhelmsen/Hagland) s. 144-145 for et tilsvarende resonnement i forhold til arbeidsgiveransvaret. 
verdiskapning som er en av begrunnelsene for arbeidet med ny lov. Preventive hensyn tilsier også at operatøren hefter fordi det er han som kan drive skadeforebyggende arbeid. ${ }^{51}$

De fleste reglene opererer med ett ansvarssubjekt, men Nederland sondrer mellom «the party whose space activity has caused damage» og «the licence holder». ${ }^{52}$ Utvalget diskuterte om det er grunn til å la både operatør og eier av romgjenstanden være ansvarssubjekt, men konkluderte med at det er tilstrekkelig å knytte ansvar til operatøren. ${ }^{53}$ Det er operatøren som søker og evt. får tillatelse og som er foreslått som pliktsubjekt for alle lovens bestemmelser. Lovutkastet foreslår også forsikringsplikt for å finansiere ansvaret. Hvis flere parter ble pålagt slik forsikringsplikt måtte hver part betale premie for sin ansvarsforsikring. Samtidig skal skadelidte eller staten kun ha dekning en gang, slik at to forsikringer ikke leder til noe høyere erstatningsbeløp for den enkelte skade. Dobbel forsikringspremie vil derfor ikke gi noen $\emptyset$ konomisk gevinst som står i forhold til økningen i premiebeløpet. Tvert om vil et slikt opplegg kunne føre til ressurskrevende regressoppgjør mellom flere ansvarsforsikringer som kun har som funksjon å flytte tap, ikke skape inntekter. I norsk rett ser man et tilsvarende resonnement ved kanalisering av oljesølsansvar etter sjøloven ${ }^{54}$ og petroleumsloven ${ }^{55}$ og ved bruk av knock for knock ${ }^{56}$ regulering i petroleumssektoren. ${ }^{57}$

Verken Sofia-modellen eller de nasjonale reglene som diskuteres her har gått så langt at man kanaliserer ansvaret til operatøren, og dette ble heller ikke diskutert i det norske utvalget. Om det er en annen enn operatøren som faktisk er ansvarlig for skaden, vil derfor operatøren ha regress mot denne etter skl. §5-3 om regress mellom to ansvarlige skadevoldere med mindre skadevolder og operatøren har en knock for knock avtale som sier at hver part dekker sine skader. ${ }^{58}$ Dette kan føre til en rettferdig fordeling av ansvar tilpasset skyld og tilfredsstille preventive hensyn, men betyr at andre involverte parter må sørge for forsikringsdekning selv om de ikke er angitt som ansvarssubjekt i loven. Dette fordyrer aktiviteten samtidig som risiko for erstatningsansvar skaper manglende forutberegnelighet for deltagerne. Flere ansvarsforsikringer skaper også risiko for ressurskrevende regressoppgjør, jf. ovenfor. Effektivitetshensyn kan derfor tale for at samarbeidende industri parter benytter seg av knock

51 Wilhelmsen/Hagland s. 144-145 og s. 50 flg.

Nederlandsk RL sec. 12 nr. 1 og 2.

Rett i bane s. 105 .

Sjøloven $\S 185$ og $\S 193$.

Petroleumsloven $\S 7-4$.

Knock for knock prinsippet betyr at partene gjensidig fraskriver seg rett til å kreve erstatning fra en kontraktspart og forplikter seg til å tegne forsikring som dekker skade på egne interesser. Ansvaret kanaliseres derfor til skadelidtes forsikringer.

57 Se nærmere Knut Kaasen, Tilvirkningskontrakter, 2018 (Kaasen 2018) Del VIII; TrineLise Wilhelmsen, Liability and insurance clauses in contracts for vessel services in the Norwegian offshore sector - the knock for knock principle, SIMPLY 2012 (Wilhelmsen 2012) s. 81-111; Hans Jacob Bull, Tredjemannsdekninger i forsikringsforhold, Oslo, 1988 (Bull 1988) Del IV.

58 Se nærmere Trine-Lise Wilhelmsen, Regress i skadeforsikring, TfE 2019/1 (Wilhelmsen 2019) kap. 3. 
for knock reguleringer som allerede er utviklet internasjonalt i bransjen, jf. nedenfor kap. 5.3.3.

\subsection{Operatørens regressansvar}

Utvalget foreslår i $§ 23$ at staten kan kreve regress fra operatøren av romgjenstanden dersom Norge i henhold til internasjonal avtale har utbetalt erstatning for skade voldt av romgjenstanden. Forslaget har sammenheng med statens ansvar etter Romtraktaten og Ansvarskonvensjonen. I den utstrekning staten selv er operatør er staten ansvarlig for skade voldt av romgjenstanden som oppskytende stat, og det er ikke noe annet ansvarssubjekt å rette regresskravet mot. Dette gjelder både oppskytning fra norsk territorium og oppskytning fra utenlandsk anlegg, jf. ovenfor kap. 3.

Utviklingen i romindustrien har imidlertid som nevnt ført til at også private aktører driver med romaktivitet, og staten kan derfor få et erstatningsansvar etter konvensjonene hvis en privat eiet romgjenstand volder skade. Konvensjonsansvaret er objektivt for skade på annen traktatparts territorium eller fly under flygning. Norge kan ikke fraskrive seg dette ansvaret ved å gjøre en privat operatør med norsk tillatelse objektivt ansvarlig for disse skadene. Hvis staten dekker et ansvar som den private operatøren er ansvarlig for etter alminnelig norsk erstatningsrett, vil staten imidlertid ha rett til regress etter reglene om to ansvarlige skadevoldere i skl. § 5-3. Et slikt regressoppgjør skal skje etter en vurdering av ansvarsgrunnlaget og forholdene forøvrig. Det er ikke gitt at staten tilkjennes $100 \%$ regress etter en slik regel.

Skal staten være sikker på full regress i enhver situasjon hvor staten blir ansvarlig etter Ansvarskonvensjonen og ansvaret er regulert av norsk rett, må dette derfor lovfestes. En slik regel finnes i Sofia-modellen $\S 11 \mathrm{nr} .1$ og er tatt inn i de fleste nasjonale reglene. ${ }^{59}$ Dette gir en «back to back» løsning hvor operatørens ansvar blir det samme som statens ansvar i den utstrekning ansvaret ikke begrenses.

\subsection{Operatørens direkte erstatningsansvar}

\subsubsection{Objektivt ansvar for skade voldt av romgjenstand på jorden og fly under flygning}

\subsubsection{Utvalgets forslag}

59 Dansk RL $\S 12$, finsk RL $\S 7$ annet ledd, svensk RL 6§, østerisk RL § 11, belgisk RL art. $15 \S 1$, nederlandsk RL sec. $12 \mathrm{nr}$. 1, fransk RL art. 14. I Norge finnes en slik regel i ekomloven § 6-7 første ledd (men ikke i lov om oppskytning av gjenstander til det ytre rom). 
Ansvarskonvensjonen gjelder ikke skade voldt av romgjenstand på nasjonale interesser og heller ikke for skade som rammer deltagere i samme utskytningsoperasjon. ${ }^{60}$ For Norge er dette særlig praktisk ved utskytning fra Andøya. Den største skaderisikoen knyttet til romvirksomhet er nettopp at noe går galt under utskytningen slik at raketten eksploderer og volder skade på norske interesser eller interesser tilhørende parter som deltar i samme utskytning, f.eks. ved bruk av utenlandsk rakett eller nyttelast.

Risikoen for slike skader må derfor reguleres av regler om direkte erstatningsansvar. Utvalget foreslår her i § 21 objektivt ansvar for operatøren for skade forårsaket av romgjenstand på personer og eiendom på jorden samt luftfartøy under flyging. ${ }^{61}$

Det objektive ansvaret er i tråd med statens konvensjonsansvar (og evt. operatørens regressansvar) for skade på annen traktatstats territorium og luftfartøy under flygning. Et slikt ansvar stemmer også med Sofia-modellen art. 11 b nr. 1 og med den danske loven $§ 11$ stk. 1 og den franske loven art. $13 \mathrm{nr}$. 1. Det finske systemet er mer komplisert fordi staten dekker alle skader forårsaket av romgjenstand i første hånd, ${ }^{62}$ men har regress mot operatøren. I utgangspunktet er regressretten begrenset til skader operatøren er ansvarlig for etter den finske skadeerstatningsloven, men for skade «on the earth or to aircraft in flight or its passenger or crew member» er operatørens regressansvar objektivt. ${ }^{63}$ Ingen av reglene refererer til Ansvarskonvensjonen og omfatter derfor skader som er underlagt nasjonal jurisdiksjon. $^{64}$

\subsubsection{Det objektive ansvaret og norsk erstatningsrettslig tradisjon}

Det objektive ansvaret for skade voldt av romgjenstand passer godt inn i den norske tradisjonen med ulovfestet objektivt ansvar for farlig bedrift, i hvert fall slik dette var utviklet før HR-2019-52 A «Spinning)». Dette var også en vesentlig grunn til utvalgets forslag. ${ }^{65}$ Betingelsene for å ilegge ulovfestet objektivt ansvar er generelt at det dreier seg om en stadig, typisk og ekstraordinær risiko for skade som etter en interesseavveining bør bæres av skadevolder. ${ }^{66}$ I nyere rettspraksis har man særlig lagt vekt på spørsmålet om risikoen er ekstraordinær, som da betyr at risikoen ved den skadevoldende virksomhet eller innretning er vesentlig større enn den man generelt møter i samfunnet. Det avgjørende for vurderingen er risikoens skadeevne - produktet av sannsynligheten for skade og mulig skadeomfang. ${ }^{67}$ Med

60 Ansvarskonvensjonen art. VII (a) og (b).

61 Se Rett i bane s. 143-144 og utvalgets alminnelige vurderinger s. 107-108.

62 Finsk RL sec. 7

63 Finsk RL sec. 7 annet og tredje ledd

64 Slik også Peter Hulsroj og Anja Nakarada Pecujlic, New in the nest: The Danish Space

Act, Air and Space Law 41 no 6 (2016) s. 503-510 på s. 507 om den danske bestemmelsen.

65 Rett i bane s.107-108.

66 Se nærmere Wilhelmsen/Hagland s. 218 flg., Hagstrøm/Stenvik, Erstatningsrett, 2 utg. 2019, s. $174 \mathrm{flg}$.

67 HR-2019-52 A «Spinning» avsnitt 35 med referanse til Rt-1991-1303 «Gulvluke». 
dette som utgangspunkt får kravet om «stadig» liten selvstendig betydning fordi det konsumeres av spørsmålet om sannsynligheten for skade. ${ }^{68}$

Sannsynligheten for fremtidig skade beregnes etter sannsynlighetsteori mellom 0 og $100 \%$ og fastlegges normalt ut fra statistisk erfaring med tidligere skader. I tidligere dommer om ulovfestet objektivt ansvar har kravet til sannsynlighet for skade ofte vært lite presist formulert og man kan få inntrykk av at det er tilstrekkelig med en iboende mulighet for skade uten hensyn til tidligere skadehistorie. ${ }^{69}$ I HR-2019-52 A «Spinning» foretar Høyesterett imidlertid en langt mer konkret vurdering av skaderisikoen med utgangspunkt i omfanget av bruken av det skadevoldende apparatet (en spinning sykkel) over tid og i flere treningssentre. Treningssenteret hadde organisert spinning siden år 2000 med 10-15 timer per uke. Setebolten var brukket to ganger, og kun en gang med personskade som følge (avsnitt 39). Produsenten av sykkelen kjente kun til et annet tilfelle hvor bolten var brukket. Høyesterett konkluderer på denne bakgrunn med at skaderisikoen er liten «når den sees i lys av spinningaktivitetens omfang» og at sannsynligheten for skade må anses for lav (avsnitt 40). Treningssenteret ble ikke ilagt ansvar.

En slik tilnærming kan vanskelig føre til ulovfestet objektivt ansvar for skade voldt av romgjenstand. Det har hittil bare vært reist et formelt krav under Ansvarskonvensjonen, ${ }^{70}$ og sannsynligheten for skade er derfor liten. Høyesteretts tilnærming kan imidlertid ha sammenheng med at selv om det dreide seg om en personskade, ble skaderisikoen vurdert som liten. Høyesterett viser til at skadens mulige omfang ikke er alvorlig. Den aktuelle skaden utgjorde $19 \%$ medisinsk invaliditet og måtte betegnes som moderat (avsnitt 41). Andre skader var ikke kjent. I tidligere dommer hvor det har dreiet seg om eksplosjonsrisiko har sannsynlighetsvurderingen ikke fått en så fremtredende plass. ${ }^{71}$ Det samme gjelder tidligere dommer med kollisjonsskader pga. teknisk svikt. ${ }^{72}$ Det fremstår derfor som uklart hvor store krav som skal stilles til sannsynligheten for skade for at det ulovfestede objektive ansvaret skal slå inn hvis det dreier seg om aktivitet som generelt fremstår som mer risikofyllt enn bruk av en spinningsykkel.

På den annen side er det klart at om det skjer en skade, kan omfanget bli stort. Dette gjelder særlig under oppskytning. Selv om de partene som er involvert i oppskytningen kan ha en kontraktsfestet ansvarsfordeling, kan en slik skade også ramme utenforstående.

Skadepotensialet hvor en rakettdel eller satellitt faller ned og kolliderer med et fly eller treffer jordoverflaten kan imidlertid også være omfattende. En slik skade vil også være «typisk» for

68 Hagstrøm/Stenvik s. 205-206.

69 Se f.eks. Rt-1991-1303 «Gulvluke», Rt-1993-1201 «Lettbetong», Rt-2006-690

«Lillestrøm».

70 Se notat fra Steven Freeland publisert i Rett i bane, Vedlegg 4 s. 171-172 og Rett i bane s. 109.

71 Se f.eks. Rt-2006-690 «Lillestrøm» og fra tidligere Rt. 1983-1052 «Gol Bygg», Rt. 1909851 «nallperle I», Rt-1875-330

72 Rt-1916-9, Rt-1921-519, Rt-1937-563, Rt-1954-739 og Rt-1955-741. 
romaktivitet fordi det nettopp er dette risikopotensialet som kjennetegner aktiviteten. ${ }^{73}$ Det er heller ikke ukjent i rettspraksis at det mulige skadeomfanget er det bærende argumentet for ansvar. ${ }^{74}$ Om det mulige skadeomfanget gir tilstrekkelig skadeevne ut fra en sannsynlighetsvurdering synes likevel i dag mer tvilsomt enn tidligere.

Hvis man kommer til at det foreligger en ekstraordinær og typisk risiko, må det også foretas en interesseavveining. ${ }^{75}$ Relevante hensyn i denne vurderingen er interessehensyn, prevensjonshensyn og pulveriseringshensyn. Interesseargumentet bygger på at det er naturlig å plassere ansvaret hos den part som har interesse av den aktiviteten som fører til skade. ${ }^{76}$ Både næringsinteresse knyttet til kommersielle romaktivitet og andre interesser, f.eks. forskningsinteresse vil her være relevant. ${ }^{77}$ Resonnementet kan begrunnes med en rettferdsbetraktning; det er mer rettferdig at den som har glede av aktiviteten dekker skadene enn den skadelidte i en større gruppe som tilfeldigvis rammes av den. Men også hensynet til samfunnsmessig effektivitet tilsier at en virksomhet må dekke de tap den påfører andre. ${ }^{78}$

Ut fra dette kan man anføre at romaktivitet skjer i operatørens interesse og at operatøren derfor er nærmere til å dekke skaden enn en skadelidt som ikke har noen slik interesse. Særlig en operatør som driver kommersiell virksomhet for å oppnå økonomisk gevinst og kan ta hensyn til risikoen for skade i sine budsjetter er nærmere til å dekke skaderisikoen enn en helt tilfeldig skadelidt.

Det andre hensynet er hensynet til prevensjon. I rettspraksis er det lagt til grunn at trusselen om ansvar uten skyld vil motivere til å forebygge skade. ${ }^{79}$ Dette er i utgangspunktet et empiriske spørsmål som er vanskelig å måle. Forholdet mellom objektive ansvarsregler og forebyggende innsats kan imidlertid verifiseres teoretisk gjennom retts $\varnothing$ konomiske modeller om optimale ansvarsregler. ${ }^{80}$ Her kan den rettslige interesseavveiningen sees i sammenheng med departementets ønske om verdiskaping, som tilsier regler i samsvar med økonomisk effektivitet. Rettsøkonomisk teori viser at objektivt ansvar vil påvirke skadevolder til å velge et nivå for skadeforebyggelse som minimerer summen av kostnader til skadeforebyggelse og forventet skade. Ansvar for uaktsomhet vil påvirke skadevolder til å velge et aktsomhetsnivå hvor han unngår å bli ilagt et ansvar for uaktsomhet slik at han kun blir ansvarlig for

73 Hagstrøm/Stenvik s. 201-202.

74 Se f.eks. Rt-1875-333, Rt-1932-416, Rt-2000-915 «Dispril» og Hagstrøm/Stenvik s. 190.

75 Hagstrøm/Stenvik s. 212-213, Wilhelmsen/Hagland s. 229, Rt-2009-1237 (avsnitt 62) (Nordsjødykker), HR-2019-52 A (Spinning) (avsnitt 36).

76 Hagstrøm/Stenvik s. 217, Wilhelmsen/Hagland s. 230.

77 Wilhemsen/Hagland s. 230.

78 Hagstrøm/Stenvik s. 217.

79 Rt-2014-656 (Avløpsnett) (avsnitt 34), Rt-1993-1201 (Lettbetong), Rt-1972-965 (Mønepanne) s. 969, Rt. 1969.109 (Løftekran) s. 112.

80 Se bl.a. Erling Eide and Endre Stavang: Retts $\phi$ konomi, Oslo 2008, (Eide and Stavang 2008) s. 233 f., Stephen Shavell, Economic Analysis of Accident Law, 1987 (Shavell), s. $85 \mathrm{f.}$. 
forebyggende kostnader. ${ }^{81}$ I en ny sektor hvor standarden for aktsomhet kan være usikker blir et objektivt ansvar mer treffsikkert for å optimalisere nivået for skadeforebyggende arbeid. ${ }^{82}$

Det siste hensynet er hensynet til pulverisering av tapet, som betyr at det tapet som rammer den enkelte skadelidte, pulveriseres eller fordeles mellom flere personer. ${ }^{83}$ Argumentet er brukt som ledd i interesseavveiningen under vurderingen av det ulovfestede objektive ansvaret i en lang rekke saker. ${ }^{84}$ Kjernen i argumentet er at statistisk påregnelige skader kan dekkes gjennom driftsomkostningene, enten ved at virksomheten budsjetterer med en egen tapspost, eller ved å tegne ansvarsforsikring og la premien inngå som en driftsomkostning. Det har derfor nær sammenheng med interessehensynet. Det er klart at en operatør av en romgjenstand kan tegne forsikring for å dekke ansvarsrisikoen, men det er ikke uten videre gitt at premien for dette lar seg beregne på grunnlag av statistikk. Hvis sannsynligheten for skade er usikker, kan dette føre til at forsikringsselskapet legger inn høyere sikkerhetsmargin i sin premieberegning slik at ansvarsforsikring blir dyrt.

Forsikringsmuligheten for operatøren må også avveies mot forsikringsmuligheten for skadelidte. ${ }^{85}$ Personer kan beskytte seg mot ulykker gjennom ulykkesforsikring, men man kan ikke regne med at slik forsikring er tegnet og det fremstår som mer rimelig at risikoen for personskade legges på operatøren. Situasjonen ved materielle skader er annerledes. Materielle gjenstander i Norge er normalt forsikret med en forsikring som i tillegg til en liste over konkrete farer også omfatter «skade som inntreffer plutselig», ${ }^{86}$ og derfor vil omfatte skader voldt av romgjenstand. Utgangspunktet i norsk erstatningsrett er også at såfremt skaden er dekket av en forsikring mot skade på ting eller formueskade, skal tapet kanaliseres til denne forsikringen og skadelidte kan ikke rette noe krav mot den ansvarlige skadevolder. Dette gjelder imidlertid ikke når skadevolderen volder skade i sitt yrke eller erverv. ${ }^{87}$ Her ligger det derfor en presumsjon om at det ikke er grunnlag for kanalisering til forsikring mot tingsskade og formueskade ved skader voldt av profesjonelle. I så fall blir det spørsmål om forsikringspremien bør legges til skadevolder eller til skadelidte-gruppen. I en slik situasjon heter det hos Wilhelmsen/Hagland på s. 233 med tilslutning fra Hagstrøm/Stenvik s. 221 at

«I slike tilfeller bør forsikringsargumentet snarere knyttes til hvem som mest rasjonelt kan forsikre seg mot skade (billigst og mest fullstendig forsikringsdekning), enn til forsikringsmuligheten i seg selv».

\footnotetext{
81 Eide and Stavang 2008, s. 238-240, Shavell, s. 8.

82 Shavell, s. 56.

83 Hagstrøm/Stenvik s. 220, Wilhelmsen/Hagland s. 57.

84 Jf. blant annet Rt-1940-16 «Klatredommen» (som er den første dommen hvor forsikringsmuligheten løftes frem), Rt-1972-965 «Mønepanne», Rt-992-64 «P-pilledom II», Rt-2001-1646 «KOLS», Rt-2003-1546 «Røykedommen» og Rt-2014-656 «Avløpsnett».

85 Rt-2004-122 «Tannstoff».

86 Wilhelmsen, Forsikringsproduktet i skadeforsikring, Tidsskrift for erstatningsrett, forsikringsrett og trygderett 2019 nr. 3-4 s. 161 flg. på s. 167-168.

87 Jf. skl. § 4-2 jf. 4-3, se nærmere Wilhelmsen 2019 s. 14-15.
} 
Det synes nærliggende å anta at operatøren er nærmere til å finansiere denne risikoen gjennom ansvarsforsikring enn de tilfeldige skadelidte som ikke noen interesse i virksomheten eller mulighet for å vurdere den. ${ }^{88}$

Et objektivt ansvar for romaktivitet passer også inn i norsk erstatningsrettslig tradisjon med lovfestet objektivt ansvar og tvungen finansiering for visse risikoutsatte sektorer. Norske eksempler er bilansvar, yrkesskade og legemiddelindustrien. Den tanken som bærer slike systemer; nemlig at risikoen bør legges hos den aktør som har interesse av den, tilsier klart at skade dekkes av operatøren og ikke av den tilfeldige skadelidte som ikke har noen interesse i aktiviteten eller noen mulighet til å påvirke denne risikoen. Det kan også være grunn til å merke seg at slike ordninger ikke forutsetter at sannsynligheten for skade er stor. Det objektive ansvaret for legemidler er ment å dekke også skader hvor sannsynligheten er liten men skadeomfanget kan bli omfattende. ${ }^{89}$

\subsubsection{Alternativet; skyldansvar for operatøren?}

Utvalget drøftet behovet for å lovfeste et objektivt ansvar for operatøren, men tok ikke opp alternativet med å la operatøren være ansvarlig etter et skyldansvar. I internasjonal sammenheng er dette ikke uvanlig. De svenske, østeriske, belgiske og nederlandske reglene har ikke spesielle ansvarsregler. Slike skader er derfor regulert av nasjonal erstatningsrett, hvor utgangspunktet gjennomgående er et skyldansvar. Dette betyr at det blir forskjell mellom operatørens regressansvar overfor staten og operatørens direkte erstatningsansvar.

For Norge vil en slik forskjell være uheldig av flere grunner. De land som ikke har direkte erstatningsregler har heller ikke nasjonale utskytningsanlegg. Risikoen for skade på eget territorium som utløser et direkte erstatningsansvar for operatøren er derfor begrenset sammenlignet med risikoen for skade på annen traktatstats territorium som utløser statens konvensjonsansvar og regressansvar for den nasjonale operatøren. For Norge med egen utskytningsbase er forholdet omvendt; risikoen for skade på eget territorium under utskytning er større enn risikoen for skade på annen traktatstats territorium ved at en romgjenstand faller ned. Dette tilsier større behov for like regler.

Lik regulering av erstatningsreglene og regressreglene vil også redusere betydningen av tolkningsproblemene knyttet til statens ansvar som oppskytende stat når private parter skyter

88 Se for et tilsvarende resonnement knyttet til økonomisk prevensjon, Wilhelmsen/Hagland s. 55.

89 Se Rt-2000-915 «Dispril» s. 925 med henvisning til NOU 1980:29 Produktansvaret, s. 205: «De sjeldne bivirkningene med stor skadeevne er nettopp en viktig gruppe tilfeller under det objektive legemiddelansvar». 
opp romgjenstander på anlegg i utlandet. Hvis staten er ansvarlig som oppskytende stat for private parter som skyter ut f.eks. på Guiana Space Center, vil skade voldt av romgjenstand på andre interesser enn de som deltar i oppskytningen utløse statens konvensjonsansvar og regressansvar for operatøren hvis dette er regulert av norsk rett. Hvis staten ikke er ansvarlig, utløses operatørens direkte erstatningsansvar dersom norsk erstatningsrett kommer til anvendelse. Hvis dette er basert på et skyldansvar vil tolkningen av Ansvarskonvensjonen få betydning for erstatningsgrunnlaget.

\subsubsection{Unntak for skadelidtes forsett/grove uaktsomhet}

Utvalget foreslår i $§ 21$ annet ledd a) unntak fra det objektive ansvaret såfremt skadelidte har utvist forsett eller grov uaktsomhet. Dette stemmer med statens ansvar etter Ansvarskonvensjonen og dermed også med operatørens regressansvar fordi dette ikke går lenger enn statens erstatningsansvar. Et lignende unntak er tatt inn i dansk RL $\S 11$ stk. 3 og fransk RL art. 13 annet ledd, men her er regelen at erstatningen kan settes ned eller bortfalle. Den franske terskelen er videre «fault», og ikke forsett eller grov uaktsomhet. ${ }^{90}$

Løsningen med reduksjon /bortfall harmonerer bedre med nordiske regler om skadelidtes medvirkning, som i norsk erstatningsrett finnes i skl. § 5-1:

Dersom den direkte skadelidte eller erstatningss $\varnothing$ keren har medvirket til skaden ved egen skyld, kan erstatningen settes ned eller falle bort for så vidt det er rimelig når en tar hensyn til atferden, og dens betydning for at skaden skjedde, omfanget av skaden og forholdene ellers. ...

En slik regel stemmer også med rettsøkonomiske modeller for optimale erstatningsregler hvor konklusjonen er at objektivt ansvar med unntak for skadelidtes medvirkning fører til optimal skadeforebyggelse fra både skadevolder og skadelidte. ${ }^{91}$

Utvalget valgte likevel å følge Ansvarskonvensjonen. Utvalget la her til grunn at en skadelidt som utviste forsett eller grov uaktsomhet normalt ville miste sin rett til erstatning etter skl. $\S$ 5-1 og anførte også at «et rent ansvarsunntak i loven kan muligens virke konfliktdempende fordi det er absolutt og ikke skaper noen forventninger om delvis ansvar». ${ }^{92}$ Dette kan sees i sammenheng med utvalgets fokus på en næringsvennlig lov hvor hensynet til klare og forutberegnelige regler fremheves. ${ }^{93}$ Valget illustrerer også at utvalget i dette tilfellet har prioritert rettferd høyere enn samfunnsmessig effektivitet ved at skadelidte behandles likt uavhengig av om skaden er underlagt statens konvensjonsansvar og operatørens regressansvar eller operatørens direkte erstatningsansvar.

$90 \quad$ Rett i bane s. 108.

91 Eide og Stavang, s. 262 flg., særlig s. 267-268, Shavell s. 27-28, se også Trine-Lise Wilhelmsen, Rett i havn, Oslo 2006 (Wilhelmsen 2006) s. 331-332.

92 Rett i bane s. 108.

93 Rett i bane s. 40. 


\subsubsection{Særlig om ansvar under felles oppskytning}

Utvalget foreslår i § 21 annet ledd b) et unntak fra det objektive ansvaret såfremt skadelidte ble skadet under deltagelse i samme oppskytningsoperasjon. Grunnen til et slikt unntak er at deltagerne i samme oppskytningsoperasjon ikke har samme behov for beskyttelse som andre tilfeldige skadelidte. Deltagerne har like stor interesse i oppskytning som skadevoldende operatør og like gode muligheter til å beskytte seg med forsikring av egne eiendeler og personell. ${ }^{94}$

Unntaket betyr at skadelidte deltagere i samme oppskytningsoperasjon ikke kan påberope seg objektivt ansvar hos operatøren. Operatøren er ikke beskyttet av alminnelige norske erstatningsregler, som etter utkastet $\S 22$ foreslås anvendelse i alle situasjoner som ikke er regulert i $§ 21$. Det tilsvarende unntaket i Ansvarskonvensjonen er videre og omfatter både statens objektive ansvar og skyldansvaret for kollisjoner. Dette må sees i sammenheng med de avtalemekanismer som benyttes mellom stater i denne sektoren. Det er ikke uvanlig at stater som samarbeider om romfartsprosjekter har avtaler om gjensidig fraskrivelse av ansvar for skade voldt under slike prosjekter. ${ }^{95}$ Ansvarskonvensjonen legger derfor til rette for disse avtalene ved å unnta dem fra statenes ansvar etter konvensjonen.

Tilsvarende avtaler benyttes også i internasjonal romfartsindustri. ${ }^{96}$ Avtalene innebærer at partene gjensidig fraskriver seg ansvar for skade voldt på den andre partens interesser uavhengig av hva slags ansvarsgrunnlag som foreligger hos skadevolder. ${ }^{97}$ Skadelidte part kan altså ikke kreve erstatning hos skadevoldende part. Avtalene inneholder videre bestemmelser om plikt for partene til å inngå tilsvarende avtaler med andre samarbeidspartnere. ${ }^{98}$ Opplegget forutsetter at enhver deltager tegner forsikring for eget personell, materielle verdier og inntjening som vil dekke skadene. Avtalen inneholder også en plikt til å sikre at forsikringsselskapet enten inkluderer andre deltagere i prosjektet som medforsikret eller uttrykkelig fraskriver seg rett til regress mot den ansvarlige skadevolderen. ${ }^{99}$ Denne typen avtaler har lang tradisjon i norsk petroleumssektor ${ }^{100}$ og er basert bl.a. på at parter som samarbeider ikke ønsker å bruke ressurser på erstatningskonflikter samt å redusere kostnadene til forsikring. ${ }^{101}$ Ved å kanalisere tap til

\footnotetext{
$94 \quad$ I denne retning Rett i bane s. 110.

95 Se nærmere Rett i bane s. 109-110.

96 Notat fra Steven Freeland, Rett i bane, Vedlegg 5 s. 178-181. Et eksempel på en mønsterklausul fra romfartsindustrien er gjengitt i Rett i bane s. 109-110 og vedlegg 5 .

97 Mønsterklausulen 1.1 og 1.2.

98 Mønsterklausulen 1.3.

$99 \quad$ Mønsterklausulen 1.4.

100 F.eks. Norsk Fabrikasjonskontrakt 2015 (NF) og Norsk Totalkontrakt 2015 (NTK) art. 30; Kaasen, 2018 s. 799 f.; Wilhelmsen 2012 s. 87-88.

101 Kaasen, 2018 s. 765-767; Wilhelmsen 2012 s. 95-96.
} 
partenes egen forsikring mot tingskade, formueskade og personskade påført ansatte kan man redusere kostnadene til ansvarsforsikring. ${ }^{102}$

Denne avtalemekanismen reiser spørsmål om man burde følge Ansvarskonvensjonen og gjøre unntak også for ansvar etter alminnelig erstatningsrett for partene i samme oppskytningsprosjekt, eller i hvert fall gi uttrykk for at slike avtaler er godtatt. Blant de nasjonale reglene som unders $\varnothing$ kes her er det kun den franske som regulerer ansvar overfor deltagere i felles «space operation», jf. lovens artikkel 19 og 20: ${ }^{103}$

Article 19

When the insurance or financial guarantee mentioned in Article 6 as well as, if necessary, the governmental guarantee have been laid out to indemnify a third party, one of the persons having taken part in the space operation or in the production of the space object which caused the damage cannot be held liable by another of these persons, except in case of a wilful misconduct.

Article 20

In the case of a damage caused by a space operation or the production of a space object to a person taking part in this operation or in that production, any other person taking part in the space operation or in the production of the space object having caused the damage and bound to the previous one by a contract cannot be held liable because of that damage, unless otherwise expressly stipulated regarding the damage caused during the production phase of a space object which is to be commanded in outer space or during its commanding in orbit, or in case of a wilful misconduct.

Art. 19 beskytter deltagende skadevolder mot krav fra annen deltager såfremt en skadelidt har fått dekning fra forsikring, finansiell garanti eller statlig garanti. I slike tilfeller er derfor ansvaret kanalisert til forsikringen eller garantien og det blir ikke tale om noe direkte erstatningskrav fra deltagende skadelidte eller regresskrav fra en annen deltager som evt. ville vært ansvarlig etter en knock for knock klausul. Beskyttelsen gjelder likevel ikke "willful misconduct". Man godtar derfor ikke ansvarsfraskrivelsen fullt ut slik den står i mønsterklausulen, hvor den gjelder uansett skyldgrad. Art. 20 stadfester gyldigheten av en knock for knock avtale og sier at knock for knock prinsippet gjelder mellom deltagende parter $i$ et romprosjekt såfremt disse har et avtaleforhold og avtalen ikke bestemmer noe annet.

Den franske bestemmelsen illustrerer et grunnleggende problem med denne typen regulering; nemlig at det kan hevdes at knock for knock avtaler eliminerer det økonomiske motivet for skadeforebyggende tiltak og at de derfor underminerer det preventive hensynet bak erstatningsrettslige regler. I den norske diskusjonen om dette i petroleumssektoren har det vært hevdet at synspunktet er betydelig overdrevet pga. myndighetenes oppfølgning og

102 Kaasen, 2018 s. 767; Wilhelmsen 2012 s. 83.

103 Hentet fra Rett i bane s. 104 basert på Uofisiell oversettelse av den franske LOI no 2008518 du 3 juin 2008 relative aux opérations spatiales, oversattt av Centre National d' Etudes Spatiales Legal Department. 
kontroll gjennom konsesjonssystemet. ${ }^{104}$ Tilsvarende kan det for romaktivitet vises til at det foreslås omfattende regler om tilsyn og kontroll som legger betydelig vekt på risikoaspektet.

Samtidig tilsier som nevnt ovenfor rettsøkonomisk teori at slike ansvarsfraskrivelser som knock for knock reguleringen hviler på ikke er i samsvar med økonomisk effektivitet. ${ }^{105}$ Konklusjonen kan imidlertid endres når det er et kontraktsforhold mellom skadelidte og skadevolder. Den amerikanske rettsøkonomen Steven Shavell viser at det under visse forutsetninger ikke har noen betydning for skadeforebyggende adferd om man legger ansvaret for skade hos den ene eller annen kontraktspart fordi den som bærer ansvaret vil legge kostnadene ved dette inn i kontraktsprisen og den som slipper å dekke ansvaret vil være villig til å betale for dette. ${ }^{106}$ Modellen forutsetter et marked med fri konkurranse og full informasjon hos begge parter om risikoen for skade. Hvis partene ikke har slik informasjon, vil skadevolder ikke ha tilstrekkelig kunnskap til å kalkulere risikoen og skadelidte vil ikke ha tilstrekkelig kunnskap til å vite hva han skal betale for den. Da er man tilbake i den alminnelige konklusjonen om ansvar som grunnlag for optimal skadeforebyggelse.

Dette betyr at hvis begge parter i et oppskytningsprosjekt har tilgang til samme informasjon om skaderisikoen f.eks. basert på generell industrierfaring, vil en knock for knock regulering ikke påvirke omfanget av skadeforebyggende tiltak. Samtidig vil en slik regulering redusere transaksjonskostnader knyttet til erstatningskrav og oppgjør. ${ }^{107}$

Selv om avtalens konsekvenser for skadeforebyggende tiltak kan diskuteres, kan bruken av slike avtaler tale for at man inntok en særlig regulering for de parter som samarbeider om prosjektet. Utvalget kom imidlertid til at det ikke var grunn til å gå så langt: ${ }^{108}$

«Selv om det ikke er grunn til å komplisere en knock for knock klausul med et objektivt ansvar, må det som et utgangspunkt være greit at partene forholder seg til alminnelig norsk erstatningsrett. Erfaring fra petroleumssektoren viser at det er fullt mulig å lage avtalemekanismer som kanaliserer ansvar til skadelidtes egne forsikringer innenfor det rammeverket som settes av alminnelige erstatningsrettslige regler.

Utvalget foreslår derfor at det objektive ansvaret ikke gjelder for denne gruppen, men at de alminnelige norske erstatningsreglene gjelder på vanlig måte.»

\subsection{Ansvarets omfang}

\footnotetext{
104 Bull 1988 s. 355, Wilhelmsen 2012 s. 109 med referanser.

105 Eide and Stavang 2008 s. 238-240 og Shavell s. 8.

106 Den grunnleggende modellen finnes hos Steven Shavell s. $47 \mathrm{flg}$. Den er gjengitt hos Wilhelmsen 2012 kap. 4.3.2, se også Wilhelmsen 2006 s. 332-334.

107 Wilhelmsen 2006, s. 337.

108 Rett i bane s. 110.
} 
Utkastet $\S 24$ foreslår at både operatørens regressansvar og det direkte erstatningsansvaret begrenses til 600 millioner kroner med mindre myndighetene fastsetter et annet beløp i tillatelsen.

Statens ansvar etter Ansvarskonvensjonen er ubegrenset. En back to back regulering av regressansvaret forutsetter derfor at dette ansvaret er ubegrenset. Dette stemmer med det grunnleggende utgangspunktet i norsk erstatningsrett at lidt skade skal dekkes fullt ut, ${ }^{109}$ som også tilsier at heller ikke det direkte erstatningsansvaret begrenses. ${ }^{110}$ Retts $\varnothing$ konomisk teori viser også at ubegrenset erstatningsansvar er nødvendig for å sikre at virksomheten investerer i skadeforebyggende tiltak inntil kostnadene ved slike investeringer overstiger reduksjon $\mathrm{i}$ forventet skade. ${ }^{111}$ Optimal skadeforebyggelse forutsetter derfor at skadevolder blir ansvarlig for hele skadelidtes $\varnothing$ konomiske tap. Dette gjelder også dersom skadepotensialet er stort. ${ }^{112}$ Hensynet til samfunnsmessige effektive løsninger og kan derfor tale for et ubegrenset regress og erstatningsansvar.

På den annen side er det viktig for aktørene å kunne forutse sine kostnader med størst mulig grad av sikkerhet. Mangel på statistikk gjør det vanskelig å beregne risikopotensialet ved denne typen aktivitet. Risikoen for å volde skader kan finansieres ved forsikring, men enhver ansvarsforsikring har en begrenset forsikringssum. Mangel på statistikk kan også gjøre forsikring kostbart fordi forsikringsselskapene legger inn et tillegg i premien for å fange inn usikkerhet ved beregning av forventet skade. Dersom kostnadene ved forsikring blir for høye og/eller ansvaret utover forsikringssummen skaper for stor $\varnothing$ konomisk usikkerhet kan dette hemme oppstart av denne typen virksomhet. Dette vil være i strid med departementets ønske om å fremme næringsutvikling. ${ }^{113}$

Utvalget behandler regressansvaret og erstatningsansvaret under ett og drøfter ikke om det er grunn til forskjellige regler. En felles begrensning stemmer med anbefalingene i Sofiamodellen og med de nasjonale reglene som har både regressansvar og erstatningsansvar. Flere land ${ }^{114}$ regulerer imidlertid bare regress spørsmålet, og det ordinære erstatningsansvaret vil da følge alminnelige erstatningsrettslige regler hvor det normalt er fullt ansvar. Sett fra operatørens side er det vanskelig å se noen grunn til at det skal være forskjell i omfanget av regressansvaret og det direkte erstatningsansvaret. Hvis noe svikter kan det være tilfeldig om skaden rammer i Norge eller et annet land. Heller ikke preventive hensyn tilsier en slik forskjell. I begge tilfeller er det spørsmål om å etablere optimale skadeforebyggende tiltak i forhold til risikoen for skade. Derimot er det en forskjell i forhold til hensynet til skadelidte og reparasjon av skaden. Ved regressansvaret er staten ansvarlig i første hånd og velter

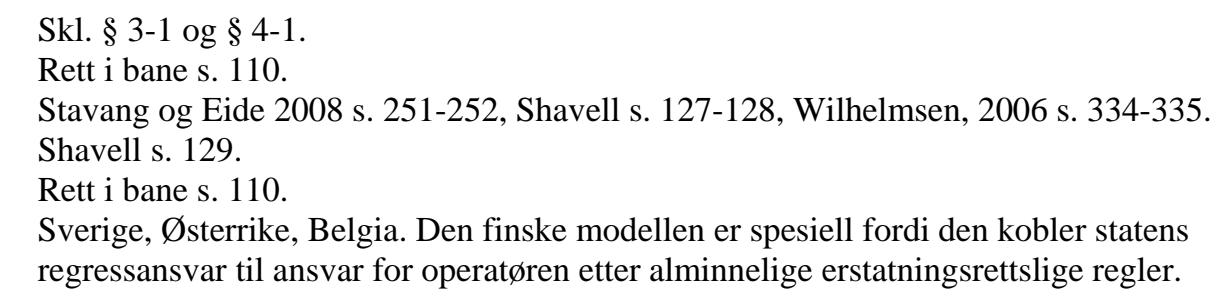


deretter ansvaret over på operatøren i en regressomgang. En skadelidt i en annen traktatstat er dermed sikret full betaling, mens en norsk skadelidt eller en som deltar i samme utskytningsoperasjon kun drar nytte av det begrensede beløpet. Dette kan derfor tilsi at det direkte erstatningsansvaret gjøres ubegrenset.

En slik løsning vil også være en fordel i forhold til usikkerheten knyttet til statens ansvar etter Ansvarskonvensjonen hvor norske selskaper skyter opp raketter eller nyttelast i utlandet. Hvis staten er ansvarlig for skade voldt av romgjenstand i denne situasjonen, er ansvaret ubegrenset. Om ansvaret påhviler operatøren direkte og dette ansvaret er begrenset, blir ansvaret forskjellig avhengig av hvilket tolkningsalternativ som er riktig.

Hensynet til likhet gir derfor ikke noe entydig svar i dette tilfellet. Heller ikke hensynet til norsk romindustris konkurransedyktighet gir et entydig svar fordi ansvarsbegrensningen i mange land kun gjelder regress spørsmålet. Men spørsmålet om konkurransedyktighet er særlig viktig i forhold til de franske reglene siden Frankrike har eget utskytningsanlegg, og her er både erstatningsansvaret og regressansvaret begrenset. Beløpet beregnes $i$ utgangspunktet for den enkelte operatør i tillatelsen, ${ }^{115}$ men i praksis krever man et forsikringsnivå på mellom $50 \mathrm{og} 70$ millioner Euro med 60 millioner som et «normalnivå». ${ }^{116}$ Sofia-modellen anbefaler også at både regressansvaret og erstatningsansvaret begrenses for å unngå forumshopping. ${ }^{117}$

Det er derfor gode grunner både til en felles begrensningsregel og til det beløpet som er valgt. Beløpet er imidlertid høyt, og differensierer i utgangspunktet ikke mellom operatører som driver utskytningsanlegg, raketteier og eier av satellitter eller annen nyttelast. Det er heller ingen differensiering i forhold til arten av den aktivitet som drives. Utgangspunktet i utkastet $\S 4$ er at all romaktivitet krever tillatelse og er underlagt lovens regler, også forsvaret, undervisnings- og forskningsinstitusjoner og private aktører. Et behov for differensiering mellom forskjellige typer aktører og aktivitet kan imidlertid skje ved at myndighetene fastsetter et annet beløp i den individuelle tillatelsen. Dette er også i tråd med løsningen f.eks. i Frankrike. ${ }^{118}$

Etter utkastets $\S 24$ annet ledd gjelder ikke begrensningen såfremt operatøren har utvist forsett eller grov uaktsomhet. De franske reglene opphever kun begrensningen ved «wilful misconduct». ${ }^{119}$ Andre nasjonale regler er strengere mot operatøren ved at man kun begrenser det objektive ansvaret, ${ }^{120}$ og flere opphever også ansvarsbegrensningen hvor operatøren har

\footnotetext{
115 Rett i bane s. 111 og vedlegg 4.

116 Rett i bane vedlegg 4.

117 Sofia modellens kommentar til art. $12 \mathrm{nr} .1 \mathrm{om}$ forsikringssum.

118 Slik også Dansk RL § 11 stk. 4 for det generelle erstatningsansvaret, belgisk RL art $15 \S 3$ for regressansvaret. En slik løsning er også forutsatt i Sofia modellen $§ 11$ nr. 2.

119 Fransk RL art. 14 tredje ledd og art. 15 første ledd.

120 Sofia modellen art 11 (a) nr. 3, se under art. 11 Comment, finsk RL sec. 7, og østerisk RL $\S 11$ (2).
} 
brutt lovens regler, ${ }^{121}$ eller har utvist skyld. ${ }^{122}$ Det er imidlertid vanlig i norsk rett at lovfestede ansvarsbegrensninger oppheves ved grovere skyldformer hos den ansvarlige, ${ }^{123}$ og brudd på lovens regler håndteres gjennom omfattende regler om tilsyn og sanksjoner i utkastet kap. 6 og 7.

\subsection{Obligatorisk forsikring}

Utvalget foreslår regler om obligatorisk forsikring eller annen sikkerhet i § 25. Dette går lenger enn hva som ville følge av det ulovfestede objektive ansvaret i norsk rett, og ligner mer på lovfestede ordninger med lovfestet ansvar og tvungen finansiering, som f.eks. bilansvaret og ansvaret for legemidler. Hensikten er dels å sikre statens regressansvar, dels å sikre at skadelidte får dekning for sitt krav.

Forslaget er i samsvar med Sofia-modellen $§ 12$ nr. 1 og det er også vanlig i de nasjonale reglene som er unders $\varnothing \mathrm{kt}$ her å ha en forsikringsplikt. ${ }^{124}$ Dette innebærer derfor like konkurransevilkår for norske operatører.

Omfanget av forsikringsplikten reflekterer ansvarsbegrensningen i $§ 24$ og er satt til 600 millioner NOK eller det myndighetene bestemmer. Også dette er i samsvar med sammenlignbare nasjonale systemer. ${ }^{125}$

Forsikringen skal dekke både operatørens direkte erstatningsansvar og regressansvaret overfor staten. En ansvarsforsikring dekker normalt bare sikredes erstatningsansvar etter alminnelig norsk erstatningsrett. Regressansvaret har etter forslaget hjemmel i norsk rett, men er knyttet til statens internasjonale konvensjonsansvar. For å tilfredsstille forsikringsplikten må det derfor fremgå klart at dette også er omfattet.

For ordinære norske ansvarsforsikringer gjelder reglene i fal. § 7-6 om direkte krav for skadelidte mot ansvarsforsikringen. Dette vil særlig ha betydning hvor operatøren ikke kan eller vil dekke kravet, men det er også generelt en fordel for skadelidte at han kan holde seg direkte til forsikringsselskapet. Dette vil særlig gjelde hvis operatøren er utenlandsk, forutsatt at skadelidte kan påberope seg norsk fal.

\section{Oppsummering}

121 Finsk RL sec. 7 fjerde ledd, belgisk RL art. 15 §, østerisk RL $§ 11$ (2).

122 Østerisk lov $\S 11(2)$.

123 Jf. f.eks. veifraktloven $\S 38$, sjøloven $\S 174, \S 185$ annet ledd og 194 tredje ledd.

124 Finsk RL sec. 8, dansk RL $\S 13$ stk. 1, østerisk RL $§ 4$ (1) nr. 7 jf. (4) og $§ 11$ (2), nederlandsk RL sec. 12 (2) jf. sec. 3 (4).

125 Nederlandsk RL sec. 3 (4) opererer med "maximum possible cover for the liability arising from the space activities» mens Finsk RL sec. 8 (1) jf. sec. 7 (4), østerisk RL sec. 4 (4) har 60 miilioner Euro. 
Artikkelen viser at spørsmålene om ansvar, regress og forsikring for skade voldt av romgjenstand er kompliserte fordi man har en kombinasjon av internasjonalt ansvar for staten, alminnelig norsk erstatningsrett for norske aktører, spørsmål knyttet til jurisdiksjon og lovvalg i internasjonale erstatningssaker og særlige risikofordelingsmekanismer som benyttes både mellom stater og i industrien.

Fremstillingen viser at spørsmålet om statens internasjonale konvensjonsansvar ved oppskytning $\mathrm{i}$ annen traktatstat foretatt av et privat norsk selskap er usikkert, men at dette bare får betydning hvis skaden overstiger ansvarsbegrensningen i utkastet. Fremstillingen viser videre at det er betydelig usikkerhet mht. hvor langt norske regler om erstatning og regress vil gjelde ved skader i andre traktatstater, særlig ved oppskytning av utenlandske raketter og nyttelast fra Andøya. Her bør det derfor vurderes om disse spørsmålene skal løses i konsesjonsvilkårene. Fremstillingen illustrerer viktigheten av harmonisering av regler for en internasjonal industri både for å sikre like konkurransevilkår for industrien og for å sikre skadelidte like rettigheter uansett hvor skaden skjer.

Analysen av det objektive ansvaret for operatøren viser at det etter Spinning dommen er en klar fordel å lovfeste det objektive ansvaret for skade voldt ved romgjenstand fordi det nå er uklart hvilke krav som stilles til sannsynlighet for skade for å utløse det ulovfestede objektive ansvaret. Et lovfestet objektivt ansvar stemmer derimot godt med andre lovfestede ansvarsordninger med tvungen finansiering som også benyttes for situasjoner hvor sannsynligheten for skade fremstår som begrenset. Det avgjørende blir da ikke om sannsynligheten for skade er stor, men at skaden kan bli omfattende om den først inntreffer, og at denne risikoen bør legges på operatøren som har interesse av aktiviteten. Et objektivt ansvar er også etter rettsøkonomiske modeller i samsvar med hensynet til samfunnsmessig effektive erstatningsregler for å oppnå optimal skadeforebyggelse. Dette hensynet bør likevel veies mot hensynet til næringsutvikling, som her særlig er vektlagt gjennom unntak fra det objektive ansvaret for industripartnere som i henhold til internasjonal praksis bruker egne ansvarsreguleringer og en begrensning mht. ansvarsrisikoen. 